\title{
RITOS DE MORTE NA LEMBRANÇA DE VELHOS*
}

\author{
Ana Lúcia Magela de Rezende ${ }^{1}$ \\ Geralda Fortina dos Santos ${ }^{2}$ \\ Valda da Penha Caldeira ${ }^{2}$ \\ Zídia Rocha Magalhăes²
}

\begin{abstract}
RESUMO: "Ritos de morte na lembrança de velhos" concretizou-se como pesquisa a partir do desconforto vivido pelas autoras em suas relações profissionais, onde a questão da morte era sempretangenciada. Caracteriza-se como uma investigaçãode inspiração fenomenológica, que utilizando-se do relato oral de sujeitos de terceira idade, procurou recuperar, decodificar e interpretar os ritos mortuários. Dos depoimentos surgiram as unidades de significado: Sentimentos e Significados diante da Morte; A Hora da Morte; A Morte Anunciada; Preparativos do Corpo; A Sentinela; O Cortejo Fúnebre; A Última Morada; A Volta para Casa; A Morte Lembrada; e sobre elas incidiu a nossa análise. Esta nos possibilitou a compreensão do vivenciar a morte, refletir as atitudes dos profissionais de saúde ao assistir o cliente e seus familiares nesta experiência existencial do ser-para-a-morte. A morte racionalizada pelo conhecimento científico, impessoalizada nos cuidados tecnologizados esconde novos ritos, transmutados pelas novas representações que a sociedade construiu.
\end{abstract}

UNITERMOS: Atitudes perante a morte - Rituais funerários - Idosos-Equipe de assistência ao paciente

\section{INTRODUÇÃO}

Ritos de morte na lembrança de velhos concretizou-se como proposta de pesquisa a partir da verbalização do desconforto vivido pelas autoras, em suas relações profissionais, onde a questão da morte era sempre tangenciada. Enquanto enfermeiras, sempre nos preocupou a dificuldade que os profissionais de saúde em geral, particularmente osde enfermagem, enfrentam ao lidar com a morte, em atividades cotidianas.

A morte, o enfrentamento do limite, é insuportavelmente angustiante, e esta angústia precisa ser domesticada pelas representações simbólico-sociaisque a mediatizam, relativizando, a estranheza do evento. As interpretações míticas da morte cumprem esta função: esvaziar a angústia experimentada diante de um fato ameaçadore tomar o fenômeno caótico, familiar. Fazerdele um fato sobre o qual o homem tem algum controle não requer, somente, explicações técnico-científicas.

Os ritos presentes em nossa sociedade moderna, malgrado toda tecnologia e ciência racionalista, ocupam um espaço fundamentalmente legítimo e necessário à eufemização da angústia do finir. Tais ritos têm caráter protetor da sociedade e restauram o conjunto social. Apresentam-se como teatralidades, representações de crenças, sentimentos e emoções que estabelecem a agregação social, cimentam as relações, construindo elos de ligação, pela participação de todos e decada um, numa mesma representação social .

Por considerar a morte e o seu cortejo de ritos como da ordem do societal, do pertencimento grupal, é que tentamos analisá-los como fenômeno social. A compreensão da morte e do morrer, e não a sua explicação, coloca-se para o profissi-

\footnotetext{
* Trabalho apresentado como Tema Livre no $46^{\circ}$ Congresso Brasileiro de Enfermagem. Porto Alegre, 30 de outubro a 4 de novembro de 1994.

1 Professora visitante do Departamento de Enfermagem da UFSC. Membro do Núcleo de Pesquisas é Estudos sobre Quotidiano em Saúde - NUPEQS-SC.

2 Professora da Escola de Enfermagem da UFMG . Membro do NUPEQS-MG.
} 
onal de saúde como de suma relevância, mas é também extremamente paradoxal. A formação profissional, marcada pelo modelo médico-biológico hegemônico, confere aos profissionais de saúde algum poder explicativo sobre os fenômenos da saúde-doença, vida e morte, mas não facilita a sua compreensão.

Os ritos desdobram-se em inúmeras manifestações, e estão relacionados à cultura, idade do morto, crenças e religião, mas conservam um núcleo eidético de caráter regenerador ou terapêutico, diante da angústia da finitude.

A ritualização está presente na vida contemporânea, embora sob novas formas "racionalizadas", como são as exigências da ciência e da sociedade moderna.

Encaminhar a proposta desta pesquisa através da interpretação dos ritos mortuários nos pareceu uma fecunda via de resgate do simbólico, tão subestimado na racionalidade do mundo moderno. Tal análise pode nos fornecer chaves para a compreensão do vivenciar a morte em nossa sociedade contemporânea e, particularmente, refletir sobre as atitudes do profissional de saúde no assistir os clientes e seus familiares nesta experiência existencial do ser-para-a-morte. Para nos aproximarmos da fluidez deste fenômeno, ao mesmo tempo tão concreto e tão amorfo, é preciso que empreguemos abordagens sensiveis e maleáveis mas, nem por isto, menos científicas.

Diante da precariedade da vida, o desejo de onipotência de produzir uma ciência que nos transcenda, merece ser recolocado. É o que esse cotidiano insuperável, onde se dão as nossas pequenas mortes de todos os dias, todas as perdas em direção à finitude, nos propõe pensar.

Assim, nesta investigação, tivemos como objetivo compreender a situação da morte enquanto fenômeno social, através da:

- reconstrução dos ritos mortuários a partir de depoimentos;

- tradução dos significados destes ritos;

- interpretação das simbologias ritualísticas da morte.

O estudo caracterizou-se como uma abordagem qualitativa de inspiração fenomenológica dos ritos mortuários. Optou-se pela utilização da técnica de História Oral, através de relatos de sujeitos de terceira idade. Estes sujeitos tinham idades acima de 55 anos, com memória preservada; eram de ambos os sexos, com vivências em cidades do interior e metrópole. O grupo de sujeitos para 0 estudo foi de dez.

De posse dos relatórios das entrevistas transcritas, as pesquisadoras iniciaram um processo de leitura e discussão. Dos discursos dos sujeitos emergiram as seguintes unidades de significado:

- A hora da morte: compreende o momento mesmo da morte, atitudes, comportamentos e manifestações de pessoas que participam daquele morrer.

- A morte anunciada: contempla sinais e símbolos que expressam a presença da morte na comunidade à qual pertence 0 morto.

- Preparativos do corpo: engloba todo movimento da comunidade, que se organiza para dar continuidade aos rituais fúnebres, a partir da morte constatada.

- A sentinela: compreende toda forma de manifestação comunitária e pública durante a exposição do corpo.

- O cortejo fúnebre: traduz a caminhada do local do velório ao local da inumação. Engloba formas de transporte do corpo, comportamentos e atitudes das pessoas que participam do cortejo fúnebre.

- A última morada: descreve as característicasdocemitério, das sepulturas, dos túmulos e da inumação.

- A volta paracasa: compreende as atitudes e comportamentos dos familiares e demais pessoas após a inumação.

- A morte lembrada: significa toda manifestação implícita ou explícita configurada nos sentimentos e comportamentos dos familiares e pessoas da comunidade à qual pertence o morto.

\section{SENTIMENTOS E SIGNIFICADOS DIANTE DAMORTE}

\section{Temporalidade da Morte}

\section{Tempo linear e tempo cíclico da morte}

A morte é, antes de tudo, uma questão de temporalidade. A linearidade de um tempo que começa e se esvai, até o fim previsto, mas não datado, precisa ser escamoteada. Esta precariedade do viveré então afrontadade maneira ardilosa, para poder se vivenciar, com um nivel de angústia suportável, estetempo que passa. Temse, assim, a ilusão da vitória sobre a morte. Para 
MAFFESOLI (3) , este "afrontamento do destino" é sinalizado por algumas atitudes, tais como a importância atribuída ao presente e à repetição. $O$ "presenteísmo" demonstra um querer viver com intensidade 0 agora, o instante que "precisa ser consumido, rapidamente consumido emexcesso, quando se conhece a sua precariedade" (3,p.25). Viver como se fôssemos imortais. "Eunåo falo em morte com os meus filhos (...) e eu seilá o que vai terdepois". O que vale é o hoje e este desejo de viver o presente é manifestado tanto nas formas escapistas do esbanjamento da energia, do dinheiro, do sexo; na frivolidade e no consumismo, como a contenção e na usura.

Para os sujeitos, talvez em função de suas idades, a idéia de morte assume uma relativa convivencialidade. Para "conformar-se", a pessoa "precisa sermuito vivida, muito experimentada da vida, játer sofrido bastante". Todavia, o "preparo" para a morte é sempre relativo, ambíguo, sempre "está faltando uma coisinha", e Deus reserva "um lugar paraagente acabar de completaraquilo que năo fez".

A repetição, querdas açõesque "preparam" para a transcendência, queridealizada em outra vida, além da terrena, parece delinear a ciclagem temporal, que é mediadora do enfrentamento da morte. Enquanto o tempo linear indica um nascer e um morrer, o tempo cíclico, vivido no cotidiano, na repetição das boas obras que preparam o homem para a boa morte, ou na crença numa outra vida, asseguram a continuação, instauram o nãotempo. A repetição cria a ilusão de que nada passa, roda o relógio ao contrário, inverte a roda do tempo. A linha reta do tempolinearé espichada e enrolada, portanto, aumentada de tamanho. Cada ciclo retoma sobre o anterior, não numa repetição mecânica, mas sim enriquecido pelas vivências pretéritas, segue seu curso... infinito. Alguma transformação ocorre, mas é assegurada a idéia da imortalidade, mediadora que dribla a insuportável consciência da finitude.

\section{A idade do morto}

Dependendo da idade do morto, os sujeitos informaram ter sentimentos diferentes. À morte de uma criança é atribuida maior dor, enquanto o velho, consideram-no mais próximo dela.

Embora a criança possa contar com maior complacência de Deus "...a criança, por muito rebelde que seja, Deus ama, né, a criança”. O velho, "se ele arrumar a trouxa dele bem arrumada...Deus perdoa, né?". A vida étida como um bem maior, de mais valorque a morté. Mesmo contando com o amor de Deus e, conseqüentemente, ser dispensada das "boas obras" que, até mesmo por falta de tempo, não realizou, a vida ainda é mais desejada. Assim, mesmo que a "cidade dos justos"seja delineada como um lugar de vida melhor, é aqui, no caótico mundo humano, que se deseja estar. Este futuro incerto da morte e do além dela não é desejado, sobretudo para um serque poderia muito ainda desfrutar das delícias do mundo humano.

A morte do velho é reportada como a de alguém para quem chegou a hora: “Já viveu, jáfez tudo". "(...) praticamente jánåo está vivendo muito, porque perde a sensibilidade, perde os reflexos (...) a memória (...) entåo, vai pra outra". Este depoimento, particularmente, atenta para a decrepitude na velhice, pela diminuição de possibilidadesde vida participativa, cuja felicidade deve agora ser encontrada em "outra" vida. Demonstra o esgotamento das potencialidadese o uso do tempo do viverque passou. "Já trabalhou a morrer, já viveu a vida"(...) "já realizou, já fez alguma coisa". Enquanto o velho "já fez", a criança ainda "năo fez nada". Este fazer humano assegura o estar vivo e utilizando o tempo em sua plenitude. Ossentimentos diante da morteinfantil demonstram a frustração pelo não uso do tempo que seria possível aproveitar.

\section{Espacialidade da morte}

\section{A morte e a Proxenia}

A proximidade afetiva, ou consangüínea, faz com que a perda através da morte seja mais dolorosa e de mais difícil enfrentamento. Este sentimento é caracterizado pela impotência em reverter ou interferir no evento.

Tempo e espaço aparecem, nos discursos, como dimensões significativas para os sujeitos e demarcadoras de experiências vividas enquanto singulares, afetivas, impessoalizadas e públicas:

"(...) porque o povo de hoje năo tem aquele sentimento". "(...) todo mundo eramuito junto, năo tinha uma obrigaçăo forte puxando. (...) A morte no interioreraassim, todo mundo sofria, até quem nåo era parente". "(...) A gente participava (...) porque era todo mundo muito unido, năo tinha assim esta vida diferente 
daqui, que te chama atenção para uma coisa e pra outra, que se vcltava muito pro parente, um pro outro".

Estas falas demonstram comparação entre um espaço-tempo-social, onde a proxenia era a tônica. Um tempo vivido melancólico e que passou. Um espaço outro, onde "a pessoa dependia muito um do outro", onde "não tinha obrigação forte puxando", e um outro momento-lugar, diferente, menos acolhedor, onde se sentem estrangeiros.

Acostumar com a morte e seus sinais é visto pelos sujeitos, como um processo irreversível dos tempos modernos e das cidades grandes, onde a massificação faz os sentimentos serem civilizadamente contidos. A complexidaded a vida moderna substituiu a proxenia, vivida com intensidade nos locais de origem, pelas obrigações e demandas múltiplas, dificultando às pessoas sentirem-se próximas. Os ritos tornaram-se cerimônias de convivência, maneirismos sociais, e o sentir a morte do outro é relativizado, porque ele é apenas mais um que morre, no burburinho moderno de cidade grande. A morte se desloca de sua essência ontológica para a realidade ôntica, inerente apenas àquele que morreu, portanto, a participação dos outros reduz-se à exterioridade da aparência.

\section{A morte e o hospital}

Ohospital é visto não só como o lugaradequado para se morrer, mas também como lugar restrito, onde os familiares têm acesso relativo. A impregnaçãoda morte fica distanciada da moradia e também dos familiares. As marcas, os sinais da morte ficam assim reservados a um lugar impessoal, longe doslugares de afeto e convívio.

Se a escolha do lugar fosse a própria casa, por ser mais familiar, espaço de proxemia, por outro lado as marcas desta morte impregnariam este local de lembranças dolorosas, com as quais a família teria de conviver:

"Foi aqui nesta sala que ela esteve (...) Para meus filhos nåo guardarem aquela hora triste na casa, parece que o hospital é menos duro para a familia".

Anular os sinais da morte, mobilizá-los na espacialidade não conhecida e distanciada da vida cotidiana e, para tal, abrir mão do conforto emocional.que a casa pode proporcionar àquele que morre. Aambigüidade é insolúvel. Permanecer "até o último minuto", ou entregar o parente, o amigo a mãos estranhas, mesmo que tecnicamente competentes, num momento de tanta vulnerabilidade? As dúvidas, nas quais merguIham estes discursos, são águas escuras e profundas e nos permitem apenas indagar: quanto de racionalismo moderno, a sufocar o desejo em função da pragmaticidade, permeiam estes discursos?

\section{Crença na vida além da morte}

O além da morte se coloca como um mistério, mas este "outro lado", nos discursos, é uma espacialidade para a qual se prepara, leva-se uma bagagem - o que se fez do lado de cá. O enfrentamento do que aguarda o morto do "outro lado" é mediado pelas boas ações que se praticou enquanto vivo. É importante que na prestação de contas, o saldo seja positivo para o ingressante no além.

Volta a figurar nos discursos, a idéia da repetição, do tempo cíclico, da transformação, mas não do acabamento. "Por que eu vejo uma planta, uma planta que nunca acaba, mesmo que morra, fica uma semente, fica uma...é uma transformação". A metamorfose, tão estudada pelos interessados das culturas orientais, onde as fronteiras entre os mundos natural e sobrenatural mostram-se tênues, é uma presença. Esta presença explicitada na cosmologia, nos rituais e mitos, permite que através de códigos moventes a reconstrução ocorra (7) . Lá, o outro lado, é uma continuação do lado de cá, onde o julgamento vai se processar a partir das obras realizadas aqui, e assim, será conferido ao entrante um lugar.

A repetição é assim uma maneira de negociar com a morte, domesticando a idéia do "nunca mais".

\section{Morte e mana}

À morte e ao morto são conferidos poderes mágicos. Embora um outro sujeito assegure não sentirmedo e que o "mortonåo faz mal a ninguém, tenho medo é de vivo", a associação entre a morte e o podermágico é representação sempre presente, ao longo da história do homem. MAUSS ${ }^{(4)}$ vai denominar "mana" essa força sobrenatural e indefinida e faz dela uma categoria de análise sociológica:

“O mana não é simplesmente uma força, um 
ser, é também uma qualidade e um estado (...) qualidade mágica de uma coisa, coisa mágica, ser mágico, posse do poder mágico, ser encantado, agir magicamente". (4, p. 162)

Esta mágica, ligada à morte, remete à noção da impureza e da conspurcação. A morte já foi vista como impregnada de miasmas, e chegou-se mesmo, na Europa do século XVIII, a formular-se uma "teoria miasmática".

A compulsão da lavar tudo, mesmo que o velório seja "limpinho": (...) eu tiro e tomo banho inteirinho, que tudo que está èmmim vaipraágua (...) sinto um pouco de náusea, um pouco de nojo", demonstram que a representação miasmática sobrevive a todo cientificismo explicador.

A poluição d'a morte é uma representação social fortemente marcada na diversidade das culturas humanas. Ela remete à idéia angustiante da desordem e do descontr.

desordem é a morte. Ela estraga o padrão da plenitude desejada. A ordem precisa ser recomposta e o banho, a preocupação com a limpeza, não estão aqui atreladas à questão estética ou meramente higiênica. Tal preocupação assume um caráter simbólico não traduzível meramente em asseio. DOUGLAS(2) sustenta que nossas concepções sobre sujeira não são somente higiênicas, mas também ritualísticas, integradas a um sistema de símbolos nem sempre facilmente explicitado.

\section{A hora da morte}

Na Idade Média até meados do século XVIII, a morte fazia parte do cotidiano das pessoas, existindo assim, uma relação de proximidade entre os vivos e os mortos. A imagem que se tinha da morte era mostrada através de duas principais características: a simplicidade familiar e a sua publicidade, sendo que o morrer em público persistiu até o fim do século XIX.(1)

A morte era regulamentada por um ritual costumeiro, ela não se apoderava, traçoeira, da pessoas. Sendo assim, algumas pessoas tinham pressentimentos sobre o momento de sua ocorrência.

A crença de que a morte avisa, e de que a pessoa que vai morrer, é quem comunica a sua própria morte, aparece no depoimento de $D$. Raimunda, quando ela busca, na memória, as lembranças da morte de sua avó.

“De manhã ela disse: Olha, prepara que eu vou morrer hoje às cinco horas, (...) prepara, manda fazer biscoito, fazer bolo".

O moribundo presidindo à própria morte, sendo o centro de todas as atenções, isso era considerado a "boa morte". Assim, todos os parentes, amigos e vizinhos eram convocados a participar daquele morrer. Ninguém podia morrer sozinho.

“(...) antes dele morrer já estava fazendo quar-

to, porque ele ia morrer qualquer hora e não deixava sozinho" (D.Dedé).

Antigamente a morte era costumeira, familiar, existia "uma horadamorte". Uma hora importante tanto para aquele que ia morrer, como para os que ficavam, como disse D.Diva:

“(...) minha måe morreu em casa. Ela morreu cercada de todo o carinho, de todos os filhos, fizemos tudo o que a gente podia fazer".

A sensação do dever cumprido eximia todo sentimento de culpa, como facilitava a aceitação da morte.

\section{A morte anunciada}

A morte era anunciada com vários sinais. Sua manifestação mais significativa era exátamente o jeito ou a forma de repicar o sino.

A comunicação oficial de um morrer procurava preparar as pessoas da comunidade para o enterro, e as alertava sobre a perda que aquela família acabava de sofrer.

"(...) quando antigamente dava aquele sinal com o sino o dia inteiro - de hora em hora, de duas em duas horas, aquele sino fúnebre, né? (D.Raimunda)

A morte de uma pessoa impunha a intensificação das relações sociais. Cada grupo passava a exigir dos seus sobreviventes o desempenho de papéis recristalizadores, que consistiam em privilegiar determinadas relações e evitar outras. Afinal,

"(...) a morte de umindivíduo năo é um evento isolado, mas representatantos eventos quantas relaçס̃eso individuo morto mantivesse: amizades, inimizades, paternidade, filiação, aliança, propriedade... Todas essasrelaçőes, que constituem o tecido social, correm o risco de se romper, ou se rompem efetivamente". $(6, p .85)$

As pessoas não morrem mais em casa e sim nos hospitais. E nestes observamos muita dificuldade para se anunciar a presença da morte. Em geral, não fica claramente definido a quem cabe fazer esta comunicação. Então ela passa a ocor- 
rer de várias formas: o pessoal de enfermagem entra emcontato com o serviço social, quando ele existe, para providenciar a comunicação aos familiares; quando a morte ocorre à noite é a própria enfermagem que procura fazer a comunicação diretamente aos parentes, ou então, passa a informação à funerária para que ela o faça.

Existe ainda, uma outra forma em que o anúncio da morte nos hospitais se faz e que talvez seja a mais dolorosa: é a do leito vazio. Não muito raro o sistema de comunicação falha, por não ter atribuído a tarefa a pessoas certas. Ao chegarem ao hospital para visitar o seu doente, os familiares surpreendem-se com o leito vazio. Buscam informações e se defrontam com o falecimento do seu ente querido.

Aos familiares, nesta situação, cabe fazer comunicações às pessoas das relações do morto. Por sua vez, essa comunicação mais ampla, dirigida a todos os que compõem o círculo social do morto, também fica restrita por limites econômicos.

\section{Preparativos do corpo}

Aolongo da história, a necessidade do cumprimento de ritos para o enfrentamento da morte pode ser observada através do preparo do corpo.

Existiam as pessoas que se incubiam de determinadas tarefas pelo ritual estabelecido como, por exemplo, as pessoas que lavavam o corpo, costuravam roupa para o defunto e que faziam os caixões.

Lavaro corpo é o que se impunha após a morte constatada. Sobre isto os nossos entrevistados nos contaram, com uma riqueza de detalhes:

"(...) se a pessoa morreu, elas vinham [as comadres] buscava a água fria e ai jogava, punha uma gamelona debaixo da cama (...) virava um vidro de creolina na água da bacia e (...) enxugardefunto pra qué? Deixava ele lá, na cama (...) (D.Dedé).

Na vivência dos nossos entrevistados era comum o uso da mortalha para vestir o corpo do morto: A mortalha identificava o morto, falava por ele e dele enquanto sujeito social. Dizia de sua idade, sexo e posição social.

A decisão sobre o tipo de mortalha para vestir o morto era tomada pelos parentes, vizinhos, que participavam daquele rito fúnebre. Muitas vezesa pessoa teria escolhido, antes de morrer, a roupa com a qual gostaria de ser enterrada.
As descrições da feitura dos caixões são, da mesma forma que as mortalhas, bastante variadas. Eram forrados por pano de várias cores que indicavam a idade, o sexo e as posses do morto. Segundo Debret, apud REIS (5) , o branco e o rosa cobriam caixões de crianças; o azul-celeste, os das moças; o preto, os de adultos. Os panos podiam ser tafetá, seda, veludo, decorados com galões de prata ou ouro.

A importância que o caixão representava naquelas comunidades está expressa, como diz REIS(5,p 149) ", ... entre os acessorios funerários, aquele em que conduzia o cadáver era o que definia a dignidade da morte".

Aos nossos entrevistados não faltou a comparação entre a sua vivência dos ritos fúnebres no interior, e o que ocorre em nossos dias, com a influência de uma cidade com grande concentração populacional:

"(...) quando vai pro hospital já vem preparado, né? se morreu em casa, leva pro hospital, láo corpo vem preparado, né? ...inclusive acho que já vem até dentro do caixâo, né? (D. Custódia).

Os ritos fúnebres do preparo do corpo, foram transferidos para dentro do hospitais para serem executados por quem? De que forma? Essa ou essas pessoas conhecem os rituais, os quais a pessoa que morreu gostaria que fossem cumpridos? Elas conhecem o ritual que os seus familiares Ihe ofereceriam?

\section{A sentinela}

O velório era feito na casa do falecido e o que o marcava era a solidariedade. As pessoas que não estavam presentes, fazendo "quarto" ao moribundo, ao saber da morte, deixavam as "obrigaçסes" e iam velar o morto. Passavam a noite toda "vigiando" o morto, fazendo sentinela.

Na sala principal ou no quarto maior da casa, o corpo ficava, geralmente, sobre a mesa. Se a família tinha menos recursos, utilizava-se uma cama ou mesmo uma esteira. Quando o falecido eramuito grande, improvisava-se uma porta como mesa. O ambiente era de recolhimento, de tristeza, de reza e cantoria o tempo todo.

Do lado de fora, o ambiente era mais descontraído. Para passar o tempo, as pessoas, predominantemente os homens, tomavam cachaça, contavam piadas, contavam histórias. Histórias de morte, de assombração. 
As fronteiras eram tênues, demarcando a espacialidadedosagrado edo profano, relativizando uma e outra dimensão. O morto era ponto de ligação entre os ritos - cânticos e rezas - num espaço sagrado, e a festa - as comidas, bebidas, namoro-que se desenrolava num espaço profano. No espaço sagrado - a sala onde se "guardava"o defunto-não eram servidas as comidas e bebidas. A elas era reservado um espaço diferenciado - na rua, onde se acendia uma fogueira, ou no fundo da casa, na cozinha. Todavia, estes espaços estavam integrados a uma espacialidade maior - a casa do morto.

Nos velórios atuais, o espaço não é mais o da casa, mas sim um velório contratado, pago. Em geral, anexo, existem osbarese cantinas. Aqueles que desejam comer ou beber algo, deslocam-se também até este outro espaço e pagam o que consomem.

A demarcação entre os espaços sagrado e profano se absolutizam. Estes, já não integram a espacialidade maiorda casa. Embora geograficamente aproximados, não guardam mais a antiga relação. Talvez o comportamento de ir à cantina para bebere abandonaro morto esua família, jáno restrito tempo em que ocorre o velório, seja visto como desrespeitoso.

O velório, hoje anexo aos hospitais, ou aos cemitérios, mantém algumas características dos antigos velórios. Não tem mais cantoria, não tem mais reza a noite toda, mas continua sendo uma ocasião de encontro coletivo e de reagrupamento de pessoas, que, muitas vezes, só se encontram nessas ocasiões, devido a amigos comuns. Apesar da lanchonete, continua-se servindo cafezinho, leite, biscoito, não junto ao cadáver, não para todos, mas ainda existe "para darmais conforto". No dizer de RODRIGUES ${ }^{(6, p .95)}$

"Os funerais são as principais ocasiōes de encontro coletivo e de reagrupamento dos individuos. (...) Ocasióes em que os vivos fazem um espetáculo para simesmos, do qual cada pessoa é ao mesmo tempo atore espectador, compondo um sistema de signos em que se exprime a posição social do morto e a de todos os participantes em relação ao grupo familiar e à sociedade global".

\section{O cortejo fúnebre}

Os enterros, naquela época, eram muito simples, populares: caixão feito sob medida, carrega- do na alça porquatro pessoas, com sentimento de solidariedade, o que amenizava o sofrimento pela perda.

$\mathrm{Na}$ roça, no mato, os corpos eram transportados em padiolas, redes, carroça, carro de boi, bangüê. Bangüê consistia em:

“(...) amarrava o lençol em dois paus compridos, punham o cadáverassimnomeio e quatro pessoas nas quatro pontas dos paus. $\mathrm{Na}$ cidade colocava o caixăo". (D.Diva)

Dependendo da posição social do morto, usavam-se outros meios para transportar o corpo:

"Agora aqueles fazendeiros, aquele pessoal que tinha uma possezinha, tinha carro de boi, outra hora era charrete e maior parte do povo ia a cavalo". (D. Custódia)

Nas cidades e em suas proximidades, terminado o velório, o corpo era colocado no caixão, e então ia para a missa de "corpo presente" encomendação da alma a Deus. Isto póssibilitava a sua entrada no céu e, ao mesmo tempo, garantia a sua saída deste mundo, seu não retorno à terra dosvivos.

Antigamente 0 enterro era feito com muito sacrifício. A maioria das pessoas ia a pé, caixão carregado por quatro pessoas. Hoje, mesmo nos lugares onde não há muito recurso, o enterro é mais fácil:

"Isso agora já tem carrinho; já tem uma empresinha lá, nesse lugar pequeno, entăo, cada um empurra um bocado, empurra na estrada, a Rio-Bahia". (Sr. João)

\section{A última morada}

Os cemitérios eram sempre no alto de um morro, pequenos, afastados da cidade, muro pintado de branco, separando o mundo dos vivosdo mundo dos mortos. A inumação simbolizava a saída definitiva do morto da sociedade dos vivos e sua entrada no reino dos mortos.

Independentemente do papel desempenhado pelo morto na sociedade, todos tinham seu espaço delimitado pela cova (ou túmulo), e pela cruz (ou lápide) identificando o "proprietário"daquele espaço.

Atualmente os cemitérios são ainda num morro, mas, cada vez mais disfarçados de acordo com as representações que hoje se tem da morte. Música ambiente, vista para um lago, colinas com árvores, sem aqueles sinais da morte, de antigamente - sepultura, cruz, mausoléus, lápide de 
família.

Hoje estes espaços são confundidos com a natureza, e até mesmo atenuados por ela. As sepulturas, quando visiveis, são discretíssimas. Assim, como diz RODRIGUES (6,p.1

A morte é maquilada e por isso dificilmente visível em sua verdadeira fisionomia. Ele [o cemitério] corresponde à versão moderna da imposição de silêncio à morte."

\section{A volta para casa}

Terminado o enterro, as atenções dospresentes se deslocam do morto para os familiares:

"Depois do enterro, o pessoal costumava voltar para casa juntos, para dar assistência à familia. "(D.Raimunda)

O "voltar para casa juntos", "a uniåo" nos traz à memória a noção de socialidade que expressa "uma solidariedade de base que une os habitantes de um mesmo lugar" (3,p 52). No pensamento de MAFESSOLI(3) , a noção de socialidade ultrapassa a noção de social (racional) e incorpora todas as minúsculassituações vividas no cotidiano societal. Nesse sentido, o "ser-junto-com" assume um caráter mediador entre o que é real, uma situação de morte, de perda, e o que se imagina, que se pode fazer diante de tal situação. $E$, neste momento, o que importa é "não deixar a gente sozinho", em que "a gente"que é o outro hoje, pode ser o "nós" amanhã.

Por outro lado, o mito da imortalidade e o tabu da morte, marcas da sociedade modema ocidental, engendram novos ritos que dinamizam comportamentos e atitudes de pessoas e grupos sociais consonantes com os valores modernistas. Daí, surgem formas diferenciadas, "racionalizadas" condizentes com a sociedade atual, como nos mostra a fala de D. Auxiliadora:

"Depois do enterro aqui a pessoa esquece [a morte] com mais facilidade. Acho que é a ocupaçăo, a vida é mais agitada, parece que o pessoal distraimelhor. No interiorficavadiase dias, ninguém tinha outro assunto, ninguém comentava outra coisa, só a morte da pessoa. E aqui, não; vocêvaiao enterro, depois que sai do cemitério cada um vaiviver sua vida normal"

\section{A morte lembrada}

O que pudemos observar é que a prática do luto, principalmente no que se refere ao seu sinal exteriorizado - o uso da cor preta no vestuáriovaria de acordo com o grau de estreitamento do vínculo social com o morto. É o que nos falaram os nossos entrevistados:

"Quando o parente era muito próximo, pai, måe, filho, vestia o luto fechado, (...) quando era distante punha uma tarja preta no chapéu ou no braço". (Sr. Petrônio).

A partir das representações simbólico sociais do luto, observamos que, de um lado, era deverdo enlutado manterum isolamento do convívio social, e este isolamento só podia ser quebrado quando fosse para participar de ritos de cunho religioso. Isto porque os ritos de expressão religiosa, nas situações de morte, já fazem parte do ritual fúnebre. E a Igreja passa a ser um espaço para consternação individual e coletiva, onde as pessoas podem liberar suas reações emocionais, provindas das lembranças daquele que morreu recentemente. Por outro lado, a cor preta do vestuário incorporava, ou deveria incorporar, todas as manifestações detristeza e dor, mostrando, simbolicamente para todo o grupo, ou comunidade, o estado de espírito da pessoa que perdeu um parente próximo. Se alguém não se vestia de preto, era sinal de que "(...) năo tá ligando pra pessoa que morreu"(Sr. Petrônio).

Sehá meio século atrás, na lembrança dos entrevistados, a morte era mostrada e lembrada em todas as suas manifestações e dimensões, hoje ela perdeu o espaço para sua exteriorização dando lugar a novos "ritos racionalizados". A cor preta, por exemplo, passa a simbolizar o "luxo"e oluto permanece e se transforma num sentimento contido, não exteriorizado.

“(...) a pessoa tem que ter luto é por dentro, é no coração. "(Sr.Petrônio)

"Oluto[vestuário] nåo representa o sentimento, o sentimento está dentro da pessoa, estálá dentro escondido, ninguém ve". (Sr. Reservindo)

\section{CONSIDERAÇÕES FINAIS}

A morte, enquanto fenômeno extremo, para ser integrada socialmente, exige que dela se elaborem representações. Racionalizada pelo conhecimento científico, modernizada na construção das manifestações, impessoalizada nos cuidados tecnologizados, esconde novos ritos, transmudados pelas novas representações que a sociedade desenvolveu da morte.

Os ritos persistem obscurecidos pela 
praticidade do mundo moderno. Subsistem ligados ao imaginário coletivo com o rico acervo da história da humanidade.

A imortalidadedos ritos mortuários, a vitalidade com que perfuram a camada densa da razão, demonstra que conservam, na sua reatualização, seu forte potencial terapêutico. As representações sociais da morte, manifestada nos ritos, restauram o tecido social por ela fragilizado.

Avanços tecnológicos e de conhecimentos médico-biológicos determinaram a medicalização social, e fizeram do ser humano um consumidor de cuidados de saúde. Todavia, não afastaram a angústia do homem diante da morte, apesar da parafernália da tecnologização da saúde. A ciência não pode curar o homem da morte, nem do medo que ela suscita. Nestas frestas os ritos se insinuam, como mediadores para este enfrentamento. Recompora perda, gerenciaradesordem causada pela morte, integrá-la no cotidiano, ajudar a aceitar o fenômeno com sua estranheza, são funções das ritualísticas mortuárias.

Nos rituais, gerenciados pelas poderosas instituições hospitalares, os profissionaisde saúde assumem os papéis da sociedade. A impessoalidade institucional apenas camufla 0 ser-ai dos profissionais. A aparente frieza com que recebem esta onerosa carga de prestar os últimos cuidados ao moribundo, ao corpo morto, e aos familiares, possibilita outras leiturasque devem ir além do estereótipo. E é também, como seres humanos, que se deparam com a morte do outro, e esta explicita as suas próprias mortes.

Todavia, esta carga desagradável do lidar com a morte é atenuada pela indiferença construída do profissional de saúde. Estereotipado na imagem daquele "acostumado" a esta tarefa, impõe-se a ele (e ele mesmo se impõe), a repressão das manifestações emocionais, escondendo no energismo, na aparente dureza e praticidade, o vitalismo humano do ser-aí-com-os-outros.

A paixão, que se manifestanos sentimentos puros, se exterioriza nas várias máscaras, dentro da teatralidade social. MAFFESOLI ${ }^{(3)}$ reporta, ao analisar a sexualidade, aos comportamentos hiposexuais dos mártires e devotos da cristandade, onde o corpo erasupliciado para abafaros desejos carnais. Nesses suplícios podem ser identificadas verdadeiras manifestações orgiásticas, e nas demonstrações da fé em Cristo, através dos suplícios, os desejos corporais também eram atendidos. $O$ profissionalismo explicitado no distanciamento do óbito poderia ser compreendido como um tipo de comportamento hipo, que se coloca como uma forma aliviadora e terapêutica desta angústia diante da morte, tal como as explosões de emoções "exageradas" em hiper. Assim, a aparente ausência de ritos, na morte hospitalizada, pode ser vista como ritos às avessas. A negação dos ritos assegura as suas presenças, perseguindo os mesmos efeitos.

O desejo, que sustentou a trajetória deste trabalho, foi tocar o intocável, soltar a voz aprisionada no mal-estar que o tema sempre causa, reafirmar o lugar privilegiado do rito na compreensão do vivido humano.

Acreditamos que, ao final deste trajeto, o texto se coloca como a incidência de luz em uma perspectiva do fenômeno, enquanto outras faces continuam obscurecidas. Desvelarcada pequeno ângulo, tendo certeza de que a inteireza da morte sempre continuará desconhecida, é tarefa na qual desejamos que os profissionais de saúde se envolvam. Estas aproximaçõessucessivas podem criar interlocuções enriquecedoras que não eliminarão o mal-estar, mas que construirão formas mediadoras do seu enfrentamento. No vivido, enquanto matéria-prima para o desvelamento do fenômeno, delineia-se uma trajetória importante para esta aproximação, impondo-se como via metodológica de eleição.

Ouvir os velhos, dar voz a este silêncio, tão ricoe subestimado, revelou-se para nós como um caminho fascinante. Um pouco da história do homem, da nossa história, ficou registrada. Os sujeitos sentiram-se tão valorizados que se mostraram perplexos. Por que as pessoas da universidade estavam precisando deles, dispunham-se a ouvi-los? O que de importante teriam eles para nos ralatar? Na riqueza deste acesso escondido, tão pouco consultado, repousa a sabedoria de quem viveu muito e tem muito a dizer, basta perguntar-Ihes. A alteridade destas experiências iluminou o caminho, alargou nosso olhar e nos fez desvestirmo-nos de nossas amaduras de profissionais, para captar o olhardo outro, diferente do nosso e tão necessário à nossa complementaridade.

Mais que entrevistados, eles foram nossos guias, receberam-nos em suas casas e com suas falas simples como é a sabedoria, entrecortadas de tropeços de linguagem, de emoção, de espanto, de prazer em se sentirem úteis, eles nos legaram pedaços importantes do seuviver. Confi- 
aram a nós um pouco das histórias de suas vidas que unimos em configurações coloridas pelo nosso entusiasmo e refreamos, no rigor epistemológico, sem todavia empobrecê-las. $\mathrm{Na}$ curva do tempo vivido, os sujeitos nosmostraram, carinhosamente, que a morte é dizível e que os ritos falam dela, mesmo no silêncio imposto pela racionalidade.

\begin{abstract}
This a phenomenologial study rites in the memory of elderly people, originated from the discomfort lived by the authors in their professional life dealing with death and dying. Verbal information from elderly people was collected with the objective of recovery and decoding mortuary rites. Nine themes originated from these informations: feelings and meanings in relation to death, the time of death, the annunciation death, the body's preparations, the watcher, the funeral procession, the grave, the retum to home, the remembered death. The results gave the authors opportunity to understand better the attitudes of health professionals in caring for patients and their families in this existencial experience of to - be - for - death. The death rationalized by scientific knowledge and nonpersonal technological care hides new rites, transmuted by new representations which the society built.
\end{abstract}

KEYWORDS: Attitude to death - Funeral rites - Ederly - Patient care team

\title{
REFERÊNCIAS BIBLIOGRÁFICAS
}

\footnotetext{
1 - ARIÉS, P O homem diante da morte. 2.ed. Rio de Janeiro: Francisco Alves, 1991. $2 v$.

2 - DOUGLAS, M. Pureza e perigo. Såo Paulo: Perspectiva, 1976.

3 - MAFFESOLI, M. A conquista do presente. Rio de Janeiro: Rocco. 1984.

4 - MAUSS, M. La prière. In: Oeuvres. Paris: PUF, 1950.
}

5 - REIS, J.J. A morte é uma festa: ritos fúnebres e revolta popular no Brasil do século XX. Sáo Paulo: Companhia da Letras, 1991.

6- RODRIGUES, J.C. Tabu da morte. Rio de Janeiro: Achiamé, 1983.

7 -VELHO, G. Projeto e metamorfose - antropologia das sociedades complexas. Rio de Janeiro: Zahar, 1994.

Encaminhado para publicaçăo em 4/11/ 94 .

Aprovado para publicaçăo em 20/2/95. 